\title{
SYSTEMIC
}

Vol. 1, No. 1, Agustus 2015, 14-19

\section{PENGENALAN CATATAN PENJUALAN MENGGUNAKAN PENGENALAN ANGKA BERBASIS KORELASI}

\author{
Ahmad Yusuf ${ }^{1)}$ \\ ${ }^{1)}$ Fakultas Sains dan Teknologi, Universitas Islam Negeri Sunan Ampel \\ Kampus Universitas Islam Negeri Sunan Ampel Surabaya, Jawa Timur \\ e-mail: ahmadyusuf@uinsby.ac.id ${ }^{1)}$
}

\begin{abstract}
Abstrak
Catatan penjualan merupakan salah satu hal penting dalam proses berlangsungnya jual beli. Catatan penjualan yang terkomputerisasi akan lebih memudahkan dalam pemrosesannya. Catatan penjualan yang berupa tulisan tangan dapat komputerisasi dengan mengenali karakter-karakter angka pada citra dokumen catatan. Metode korelasi maтри melakukan pengenalan tulisan tangan terhadap nominal pada catatan penjualan.Metode korelasi merupakan metode sederhana dalam mengenali karakter angka. Berdasarkan hasil evaluasi, metode korelasi dapat mengenali angka dengan akurasi $73 \%$ dengan parameter tertentu. Beberapa kesalahan pengenalan dapat terjadi karena karakter yang dikenali tidak mendukung template yang digunakan seperti miring atau memiliki bentuk yang berbeda sigifinikan.
\end{abstract}

Kata Kunci: korelasi, pemrosesan citra, pengenalan angka, pengenalan tulisan tangan, penjualan

Sales records is one of the important things on the trading process. Computerized sales records will be much easier in processing to get more information. Sales records in the form of handwriting can be computerized to recognize characters in the document image record numbers. Correlation method is able to perform handwriting number recognition on record sales. Correlation method is a simple method to recognize numeric characters. Based on the evaluation, the correlation method can recognize the numbers with an accuracy of $73 \%$ with a certain parameter. Some errors may occur due to the introduction of a recognizable character does not support the template that is used as tilted or have different shapes significantly.

Kata Kunci: correlation, image processing, number recognition, handwriting recognition

\section{PENDAHULUAN}

Proses jual beli merupakan proses yang tidak akan lepas dari kehidupan manusia. Proses jual beli pun terdapat dalam berbagai bidang. Dalam proses jual beli pastinya terdapat proses pencatatan yang mendukung berlangsungnya proses jual beli. Salah satu hal yang penting dalam pencatatan adalah pencatatan atau nota penjualan. Setiap transaksi penjualan akan tercatat pada catatan penjualan. Dengan adanya catatan penjualan akan didapatkan informasi yang dibutuhkan penjual. Salah satu informasi yang dapat diperoleh adalah jumlah transaksi penjualan. Pada kenyataannya pencatatan penjualan secara umum dilakukan dengan manual tanpa proses komputerisasi, sehingga proses perolehan informasi pun dilakukan secara manual atau menggunakan alat bantu seperti kalkulator. Pemrosesan catatan penjualan secara manual dapat memperlambat proses perolehan informasi bahkan mempersulit pemrosesan catatan penjualan.

Catatan penjualan yang dilakukan secara manual dapat diproses dengan memanfaatkan teknologi informasi yang ada. Salah satu cara dalam pemrosesan catatan penjualan adalah dengan melakukan proses citra dari catatan penjualan yang ada. Dari citra catatan penjualan dapat diekstraksi nominal-nominal penjualan yang terdapat dalam catatan. Proses ekstraksi dilakukan dengan pengenalan angka pada citra. Dengan adanya nominal tersebut maka dapat dilakukan 
SYSTEMIC

pemrosesan dalam memperoleh informasi, yaitu jumlah transaksi penjualan.

Pemrosesan citra telah banyak dikembangkan oleh berbagai kalangan. Pemrosesan citra pun dapat meliputi banyak hal mulai dari tahap pra-proses citra, segmentasi, pengenalan pola, dan sebagainya. Pemrosesan citra pun dapat dimanfaatkan dalam mengektrasi fitur dalam citra dokumen. Metode yang dapat dimanfaatkan dalam pemrosesan dokumen adalah pengenalan pola karakter pada dokumen. Metode dalam pengenalan karakter telah banyak dikembangkan oleh beberapa peneliti. Salah satu metode adalah menggunakan perhitungan korelasi dalam mengenali pola karakter yang dapat dimanfaatkan dalam pengenalan catatan penjualan $[1,2]$.

\section{PENELITIAN TERKAIT}

\subsection{Binerisasi Dokumen}

Salah satu langkah awal dalam pemrosesan citra dokumen adalah tahap pra-proses. Document Image Binarization merupakan salah satu metode yang dapat digunakan dalam pra-Proses pengolahan citra dokumen. Image Binarization mengubah citra gray-scale menjadi citra biner. Pada umumnya, hal inid digunakan dalam memisahkan antara latar belakang (background) dari citra dan teks itu sendiri (foreground).

Metode umum yang dilakukan pada binerisasi teks adalah thresholding [3]. Metode thresholding merupakan proses mengubah citra berderajat keabuan menjadi citra biner dengan nilai ambang tertentu. Thresholding sederhana merupakan global thresholding dimana terdapat satu nilai ambang yang berlaku pada keseluruhan piksel pada citra. Pengembangan metode thresholding adalah adaptif thresholding. Adaptif thresholding membagi bagian menjadi beberapa citra dan setiap bagian akan dilakukan thresholding dengan nilai ambang tertentu yang belum tentu sama dengan bagian lainnya. Beberapa algoritma binerisasi dikembangkan dengan menggunakan konsep adaptive thresholding. Adaptive degraded document image binarization merupakan salah satu metode binerasi yang mengadopsi konsep adaptif thresholding [4]. Metode ini merupakan pengembangan metode binerisasi sebelumnya yaitu Sauvola Thresholding yang juga menggunakan konsep adaptif thresholding [5].

Metode Binerisasi Citra pada Adaptive degraded document image binarization dibagi menjadi beberapa tahapan, yaitu tahap pra-proses, estimasi daerah foreground, estimasi daerah
ISSN: 2460-8092

background, dan thresholding. Masukan citra berupa citra berderajat keabuan [4].

Tahap pra-proses bertujuan untuk mengilangkan noise yang terdapat pada citra masukan. Metode yang digunakan dalam praproses adalah Wiener Filter. Wiener Filter menggunakan ketetanggan tiap piksel (local neighborhood) dalam pemrosesannya. Masukan citra berderajat keabuan difilter berdasarkan rumus [4]:

$$
I(x, y)=\mu+\left(\sigma^{2}-v^{2}\right)\left(I_{s}(x, y)-\mu\right) / \sigma^{2} .
$$

Dimana I merupakan citra masukan, $\mu$ merupakan local mean dan $\sigma^{2}$ adalah local variance dari $\mathrm{n} x \mathrm{n}$ ketetanggaan piksel yang diproses, dan $\mathrm{v}^{2}$ merupakan rata-rata estimasi variance tiap piksel dalam ketetanggan $n \times n$ tersebut.

Selanjutnya dilakukan estimasi foreground yang merupakan teks pada citra. Metode yang digunakan adalah pendekatan Sauvola Adaptive Thresholding [5]. Hasil dari proses ini (S) adalah citra biner dimana piksel bernilai 1 merupakan piksel yang dianggap foreground/teks.

Setelah dilakukan estimasi foreground berikutnya dilakukan estimasi background. Proses estimasi background (B) dilakukan dengan melakukan filter terhadap citra hasil pra-proses dengan rumus [4]:

$$
\begin{aligned}
& B(x, y) \\
& = \begin{cases}I(x, y) & \text { if } S(x, y)=0, \\
\frac{\sum_{i x=x-\mathrm{d} x}^{x+\mathrm{d} x} \sum_{i y=y-\mathrm{d} y}^{y+\mathrm{d} y}(I(i x, i y)(1-S(i x, i y)))}{\sum_{i x=x-\mathrm{d} x}^{x+\mathrm{d} x} \sum_{i y=y-\mathrm{d} y}^{y+\mathrm{d} y}(1-S(i x, i y))} & \text { if } S(x, y)=1 .\end{cases}
\end{aligned}
$$

Setelah itu dilakukan Final Thresholding untuk mendapatkan hasil akhir citra biner. Thresholding dilakukan dengan aturan [4]:

$$
T(x, y)= \begin{cases}1 & \text { if } B(x, y)-I(x, y)>d(B(x, y)), \\ 0 & \text { otherwise. }\end{cases}
$$

dimana d merupakan batas ambang yang dijadikan sebagai acuan binerisasi. Nilai d bisa berupa bagian dari derajat nilai piksel pada citra background (B). Untuk mendapatkan hasil yang baik maka nilai d sebaiknya lebih kecil daripada nilai tergelap (terkecil) pada citra background $\mathrm{B}$ atau nilai d dapat diestimasi dengan persamaan [4]:

$$
d(B(x, y))=q \delta\left(\frac{\left(1-p_{2}\right)}{1+\exp \left(\frac{-4 B(x, y)}{b\left(1-p_{1}\right)}+\frac{2\left(1+p_{1}\right)}{\left(1-p_{1}\right)}\right)}+p_{2}\right) .
$$

dimana $\mathrm{q}, \mathrm{p}_{1}, \mathrm{p}_{2}$ merupakan parameter persamaan.

\subsection{Segmentasi Baris Teks}

Pengenalan Catatan Penjualan Menggunakan Pengenalan Angka Berbasis Korelasi 


\section{SYSTEMIC}

Vol. 1, No. 1, Agustus 2015, 14-19

Setiap dokumen tentunya memiliki karakteristik teks yang berbeda-beda, seperti jenis huruf, ukuran, dan sebagainya. Adanya variasi karakteristik dapat menyulitkan dalam pengenalan karakter pada tulisan tangan. Salah satu hal yang dapat dilakukan adalah dengan segmentasi baris teks dalam pendeteksian tulisan tangan. Dengan adanya baris teks maka akan didapatkan daerahdaerah teks tiap barisnya sehingga dapat memudahkan dalam proses pengenalan selanjutnya. Salah satu metode yang pernah dikembangkan dalam mensegmentasi baris teks adalah dengan proyeksi histogram [6]. Dengan proyeksi histogram dapat dilihat distribusi foreground yang merupakan tulisan pada dokumen. Berdasar proyeksi histogram tersebut maka citra dapat dibagi-bagi menjadi beberapa baris dokumen.

\subsection{Pengenalan Karakter}

Pengenalan karakter merupakan suatu metode dalam mengenali citra masukan menjadi satu atau urutan karakter yang sesuai. Banyak metode yang telah dikembangkan dalam pengenalan karakter. Salah satu metode yang paling sederhana dalam pengenalan karakter adalah dengan menggunakan konsep korelasi [1].

Korelasi merupakan salah satu cara mengetahui hubungan variabel-variabel yang satu dengan lainnya. Pada pengenalan karakter, korelasi merupakan representasi dari citra karakter yang dideteksi dengan template karakter yang telah didefinisikan sebelumnya [1,2]. Pada metode ini, template keseluruhan karakter dari huruf dan angka didefinisikan dan disimpan pada variabel tertentu. Template tersebut merupakan panduan dalam menentukan karakter yang dikenali pada citra.

Citra masukan pada pengenalan karakter adalah citra biner. Jika citra bukan merupakan citra biner maka akan dilakukan binerisasi terlbih dahulu pada citra masukan. Sebelum dilakukan pengenalan, citra masukan disegmentasi terlebih dahulu menjadi baris-baris teks. Dari masingmasing baris teks kemudian dicari komponenkomponen piksel yang terhubung. Dari masingmasing komponen yang terhubung tersebut akan dicocokkan dengan template yang sudah didefinisikan sebelumnya dengan menghitung korelasinya. Keluaran yang diperoleh berupa karakter yang bersesuaian dengan template yang memiliki korelasi paling tinggi dengan suatu komponen piksel yang terhubung $[1,2]$.

\section{METODE}

Metode dalam melakukan pemrosesan citra dokumen catatan penjualan menjadi nominalnominal penjualan meliputi beberapa tahapan yaitu pra-proses, binerisasi, segmentasi teks, dan pengenalan karakter angka.

\subsection{Pra-Proses}

Masukan citra yang akan diproses selanjutnya adalah berupa citra dokumen catatan penjualan. Citra yang dimasukkan dapat berupa citra warna ataupun citra berderajat keabuan. Langkah awal yang dilakukan adalah dengan menstandardkan citra masukan menjadi citra berderajat keabuan.

Terkadang pada citra masukan terdapat noise yang dapat menganggu pemrosesan citra selanjutnya. Pada citra masukan yang telah mempunyai derajat warna keabuan tersebut akan dilakukan pengurangan noise menggunakan Wiener Filter [3]. Wiener Filter menggunakan ketetanggan tiap piksel (local neighborhood) dalam mengurangi noise pada citra masukan. Dengan penggunaan Wiener Filter akan mengaburkan noda-noda yang terdapat pada citra dokumen catatan penjualan tetapi tetap mempertahankan bagian tulisan karena menggunakan konsep adaptif filtering. Dari hasil pra-proses didapatkan citra dokumen berderajat keabuan dengan pereduksian noise menggunakan Wiener Filter. Contoh hasil dari pra-proses ditunjukkan pada gambar 1 (a).

\subsection{Binerisasi dan Segmentasi Teks}

Citra hasil pra-proses diproses selanjutnya yaitu proses binerisasi. Proses binerasi bertujuan untuk menjadikan citra yang berderajat keabuan menjadi citra yang hanya memiliki dua intensitas warna yaitu hitam dan putih. Proses binerisasi dilakukan dengan proses thresholding [3]. Proses thresholding dilakukan dengan menggunakan metode Global Thresholding. Pada metode global thresholding tersebut diperlukan satu parameter $\mathrm{t}$ yang merupakan batas nilai ambang thresholding. Parameter $\mathrm{t}$ yang digunakan dalam melakukan binerisasi pada penelitian ini akan diujicobakan untuk mendapatkan akurasi yang terbaik. Hasil dari binerisasi ini adalah citra biner hitam dan putih yang merepresentasikan background citra dan foreground citra yaitu karakter yang akan dilakukan pengenalan. Gambar 1 (b) menunjukkan contoh hasil binerisasi dari data yang digunakan.

Sebelum dilakukan pengenalan karakter, citra hasil binerisasi akan disegmentasi menjadi baris-baris karakter sehingga akan lebih mudah dikenali. Metode segmentasi baris memanfaatkan 


\section{SYSTEMIC}

proyeksi histogram dari citra masukan yang akan diproses [6]. Pada citra masukan akan dibuat proyeksi histogramnya berdasar pada sumbu y. Proyeksi histogram pada sumbu y digunakan dalam memperoleh distribusi foreground pada tiap koordinat y. Dari hasil histogram maka dapat dilihat proporsi jumlah piksel foreground yang merupakan bagian dari teks pada citra sehingga sudah terlihat teks tiap barisnya. Tahap selanjutnya adalah membagi citra dokumen menjadi beberapa baris teks berdasarkan yproyeksi histogram. Setiap daerah pada yproyeksi histogram akan dibagi oleh batas ambang berdasar pada rata-rata distribusi nilai pada histogram. Baris teks akan diperoleh dari histogram yang hampir tidak mempunyai nilai pada sumbu y nya. Hanya saja terkadang ada masalah disaat ada penumpukan karakter dari satu baris ke baris. Pada penelitian ini, nilai yang beririsan tersebut akan dihapus dari histogram berdasar pada rata-rata nilai pada histogram. Penghilangan komponen tersebut akan menimbulkan ruang kosong sehingga didapatkan daerah untuk membagi baris teks. Gambar 1 (c) merupakan salah satu contoh baris teks yang tersegmentasi dari citra biner.

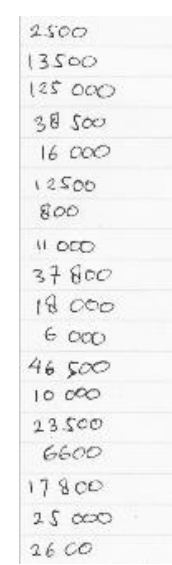

(a)

$$
\begin{aligned}
& 2500 \\
& 13500 \\
& 125000 \\
& 38500 \\
& 16000 \\
& 12500 \\
& 800 \\
& 11000 \\
& 37000 \\
& 18000 \\
& 6000 \\
& 46500 \\
& 10000 \\
& 23500 \\
& 6600 \\
& 17800 \\
& 25000 \\
& 2600
\end{aligned}
$$

(b)

(c)

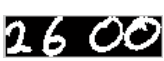

Gambar 1 Hasil dari Pra-Proses (a), Binerisasi (B), dan Segmentasi (c).

(a)

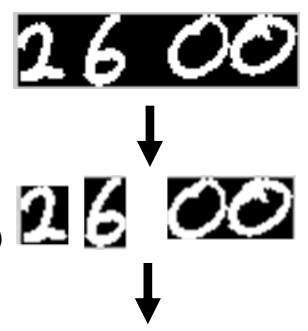

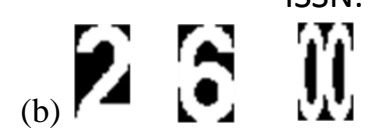

Gambar 2 Hasil dari Segmentasi Baris (a), Komponen Terhubung (b), dan Template Korelasi terbesar (c)

\subsection{Pengenalan Karakter Angka}

Dari masing-masing baris teks yang diperoleh maka akan dikenali angka-angka yang terdapat pada teks tersebut. Pengenalan hanya dilakukan pada angka karena hanya angka pada catatan penjualan yang digunakan dalam memperoleh informasi nilai-nilai penjualan.

Pengenalan angka dilakukan dengan membandingkan citra masukan masukan dengan template yang sudah didefinisikan menggunakan korelasi. Masukan pada tahap ini adalah citra dokumen yang telah dibagi menjadi baris-baris teks. Pada asing-masing baris teks akan dicari komponen-komponen yang terhubung. Dari masing-masing komponen yang terhubung akan dicocokkan dengan template karakter yang ada. Template karakter yang didefinisikan merupakan karakter angka dan karakter pendukung. Karakter pendukung yang kemungkinan ditemui dalam pengenalan citra dokumen adalah kumpulan angka 0 yaitu '00' dan '000'. Hal ini dikarenakan pada data yang digunakan menggunakan ukuran rupiah sehingga besar kemungkinan terdapat angka 0 yang terhubung satu sama lain, sehingga dari kumpulan 0 tersebut dapat dikenali.

Dari angka-angka yang dikenali maka akan diseleksi yang merupakan angka nominal penjualan. Angka nominal penjualan merupakan kumpulan angka-angka yang diakhiri dengan karakter angka '00' atau '000' karena data penjualan merupakan nilai rupiah. Dari nominalnominal penjualan dalam satu dokumen akan dihasilkan kumpulan dari nilai-nilai penjualan yang telah dikenali computer dan bisa diproses selanjutnya. Contoh pengenalan nominal ditunjukkan pada gambar 2

\section{SUBJEK EVALUASI}

\subsection{Dataset}

Dataset yang digunakan dalam evaluasi merupakan citra dokumen yang terdiri dari kumpulan nominal angka yang merepresentasikan sebagai nilai penjualan. Pada penelitian ini digunakan 125 nominal yang terbagi menjadi 5 citra dokumen, dimana masing-masing dokumen terdiri dari 25 nominal. Dari masing-masing citra 
Vol. 1, No. 1, Agustus 2015, 14-19

dokumen akan dikenali nominal-nominal nilai penjualan. Dari hasil pengenalan tersebut akan dibandingkan dengan data aslinya yang merupakan pengenalan citra dari manusia.

\subsection{Parameter Pengukuran Performa}

Adapun untuk parameter pengukur performa sistem menggunakan nilai akurasi. Akurasi dihitung berdasarkan masing-masing nominal penjualan yang dikenali. Akurasi merupakan perbandingan antara nominal penjualan yang dikenali dengan benar ( $x$ ) dan seluruh nominal penjualan (n) sesuai dengan persamaan berikut :

$$
\text { Akurasi }=\frac{x}{n}
$$

Dalam memperoleh informasi maka dapat dihitung total penjualan dari hasil yang diperoleh. Tetapi nilai total penjualan tidak dapat dijadikan parameter pengukuran karena untuk mendapatkan total penjualan diperlukan nominal-nominal yang seluruhnya benar. Jika terdapat satu nilai nominal yang salah maka total penjualan pun akan salah. Nilai total penjualan baru dapat diuji ketika seluruh nilai nominal pada dokumen penjualan dipastikan benar.

\subsection{Skenario Evaluasi}

Metode pengenalan angka pada penelitian ini menggunakan satu parameter yaitu $t$ sebagai batas ambang pada proses binerisasi. Pada evaluasi akan dilakukan dengan mengenali karakter angka pada catatan penjualan dengan beberapa nilai parameter $t$. Parameter $t$ akan diubah-ubah untuk memperoleh parameter yang mampu menghasilkan akurasi terbaik. Evaluasi juga digunakan untuk mengetahui hubungan antara parameter $t$ dengan akurasi yang dihasilkan. Evaluasi dilakukan ke semua nominal penjualan pada himpunan data yang digunakan masa masing-masing nilai parameter $\mathrm{t}$.

\section{HASIL EVALUASI}

Evaluasi dilakukan dengan menggunakan subjek dan skenario evaluasi yang telah dijelaskan sebelumnya. Interval parameter $\mathrm{t}$ yaitu antara 0 sampai dengan 1. Nilai parameter $\mathrm{t}$ yang digunakan dalam evaluasi adalah $0.7,0.75,0.8$, 0.85 dan 0.9. Dari masing-masing nilai parameter $\mathrm{t}$ akan dilakukan evaluasi dalam mengenali nominal penjualan pada dataset. Hasil dari evaluasi ditunjukkan pada tabel 1 .

\section{Tabel 1}

Akurasi dari evaluasi dengan t yang berubah-ubah

\begin{tabular}{cc}
\hline Parameter t & Akurasi \\
\hline $\mathbf{0 . 9}$ & 0.73 \\
$\mathbf{0 . 8 5}$ & 0.53 \\
$\mathbf{0 . 8}$ & 0.52 \\
$\mathbf{0 . 7 5}$ & 0.46 \\
$\mathbf{0 . 7}$ & 0.43 \\
\hline
\end{tabular}

Pada tabel 1 terlihat bahwa akurasi terbaik dicapai pada saat model menggunakan parameter $\mathrm{t}$ $=0.9$ yaitu sebesar 73 persen. Pada hasil evaluasi dapat dilihat hubungan antara parameter t dengan akurasi yaitu semakin besar nilai t maka akurasi yang dihasilkan semakin baik sampai titik optimal. Hal ini terjadi karena saat parameter $\mathrm{t}$ terlalu kecil, banyak detil yang hilang karena proses thresholding pada binerasi, sehingga beberapa angka tidak dapat dikenali dengan benar. Tetapi nilai $\mathrm{t}$ yang terlalu besar akan menampakkan noise-noise yang dapat mengganggu pengenalan karakter.

Kesalahan pengenalan juga terjadi dikarenakan data yang akan dikenali sangat tidak bersesuaian dengan template yang digunakan. Hal ini dapat terjadi karena kemungkinan posisi karakter pada citra tidak sempurna seperti miring atau memiliki variasi bentuk yang beragam. Model yang pengenalan pada penelitian ini bergantung pada template yang digunakan sehingga tidak mampu menangani permasalahan tersebut.

\section{KESIMPULAN}

Catatan penjualan yang terkomputerisasi akan lebih memudahkan manusia untuk memperoleh informasi didalamnya. Catatan penjualan yang berupa tulisan tangan dapat dikenali nominal-nominal penjualannya oleh komputer menjadi karakter-karakter angka. Metode korelasi mampu melakukan pengenalan tulisan tangan terhadap nominal pada catatan penjualan.

Metode korelasi memiliki kelebihan sekaligus kekurangan yang dapat diperbaiki dalam mengenali tulisan tangan. Metode korelasi merupakan metode sederhana dalam mengenali karakter angka, dengan begitu proses komputasinya tidak rumit dan mempunyai waktu komputasi yang relatif cepat. Hanya saja, metode ini belum mampu mengatasi berbagai keadaan pada kondisi dokumen catatan penjualan. Kesalahan pengenalan dapat terjadi karena karakter yang dikenali tidak mendukung template yang digunakan seperti miring atau memiliki bentuk yang berbeda sigifinikan. Hal ini 
membuka peluang untuk pengembangan metode selanjutnya.

\section{DAFTAR PUSTAKA}

[1] Line Eikvil. 1993. "Optical Character Recognition".

[2] Pranob K Charles, V.Harish, M.Swathi, dan CH. Deepthi. 2012. "A Review on the Various Techniques used for Optical Character Recognition". International Journal of Engineering Research and Applications (IJERA).

[3] Rafael C. Gonzales, Richard E. Woods. "Digital Image Processing, 2/E". Prentice Hall

[4] B. Gatos, I. Pratikakis, S.J. Perantonis. 2005. "Adaptive degraded document image binarization". Pattern Recognition Society Elsevier Science Ltd.

[5] J. Sauvola*, M. PietikaK inen. 1999. "Adaptive document image binarization". Pattern Recognition Society Elsevier Science Ltd.

[6] Rodolfo P. dos Santos, Gabriela S. Clemente, Tsang Ing Ren dan George D.C.
Calvalcanti. 2009. "Text Line Segmentation Based on Morphology and Histogram Projection". 10th International Conference on Document Analysis and Recognition. 